\title{
Budidaya Caisim dan Pakcoy Teknik Vertikultur dalam Rangka Peningkatan Kemandirian Pangan
}

\author{
Githa Noviana ${ }^{1 *}$, Fani Ardiani $^{1}$, Yohana Theresia Maria Astuti ${ }^{1}$ \\ ${ }^{1}$ Program Studi Agro Teknologi Institut Pertanian STIPER Yogyakarta \\ J1. Nangka II Krodan Maguwoharjo Sleman 55281 Daerah Istimewa Yogyakarta
}

*E-mail : Githanoviana48@gmail.com

\author{
DOI: https://doi.org/10.21107/pangabdhi.v7i2.11510 \\ Naskah diterima 28 Juni 2021, Revisi 27 Agustus 2021, Terbit 29 Oktober 2021
}

\begin{abstract}
Abstrak
Kegiatan pengabdian kepada masyarakat dilakukan untuk menginspirasi masyarakat kota khususnya Yogyakarta untuk dapat menghasilkan pangan mandiri yang memanfaatkan pekarangan rumah. Walaupun tidak 100\% memenuhi kebutuhan pangan sendiri, namun upaya berkebun sayur di rumah secara signifikan memotong kebutuhan logistik rumah tangga. Kegiatan ini dilakukan di Asrama Putra Sang Timur, Kelurahan Gunungketur, Pakualaman, Yogyakarta. Persiapan yang dilakukan meliputi: (a) koordinasi dengan pihak Asrama Putra Sang Timur tempat dilaksanakan pengabdian (memasukan surat ijin pengabdian), (b) persiapan yang ke dua melakukan kesepakatan penentuan peserta dan waktu pengabdian/ pelatihan, (c) Pelaksanaan, untuk meningkatkan pengetahuan siswa atau penghuni asrama untuk mengoptimalkan pekarangan asrama. Pelaksanaan yaitu melakukan penjelasan mengenai teknik budidaya pada teknologi vertikultur dan pengertian, keuntungan, model, alat dan bahan yang dapat digunakan serta tata cara penerapan teknologi vertikultur. Pelaksanaan pengabdian dilakukan secara tatap muka dengan mematuhi protokol Kesehatan. Siswa melakukan praktik langsung penanaman pakcoy dan caisim sambil dibimbing oleh pemateri. Selanjutnya penyerahan benih pakcoy dan caisim untuk penanaman berikutnya yang akan dilaksanakan siswa secara mandiri.
\end{abstract}

Kata Kunci : vertikultur, kebutuhan pangan, pengabdian masyarakat, pakcoy, caisim

\section{PENDAHULUAN}

Kebutuhan pangan terus meningkat seiring dengan bertambahnya penduduk di muka bumi khususnya Indonesia. Namun hal ini bertolak belakang dengan ketersediaan lahan yang semakin berkurang karena perkembangan disektor properti. Perkembangan ekonomi di Indonesia secara signifikan juga meningkatkan kebutuhan lahan dalam pembangunan Gedung perkantoran, perumahan dan pabrik. Pembangunan tidak hanya di wilayah perkotaan namun juga di pedesaan, sehingga alih fungsi lahan tidak bisa dihindari. Hal ini berdampak berkurangnya ketersediaan lahan untuk pertanian dalam memenuhi kebutuhan bahan pangan seperti sayuran segar (Rosyad et al., 2020).

Pangan menjadi kebutuhan utama yang harus dipenuhi, karena ini sangat berpengaruh terhadap keberlangsungan hidup secara sehat. Sejalan dengan visi misi pemerintah untuk memperkuat sektor pangan Indonesia yang dinamakan Pekarangan Pangan Lestari (P2L). Kegiatan ini berfokus untuk memanfaatkan pekarangan rumah.
Dalam visi misi ini, masyarakat berperan penting dalam pemenuhan kebutuhan pangan secara mandiri di rumah. Walaupun tidak $100 \%$ memenuhi kebutuhan pangan sendiri, namun upaya berkebun sayur di rumah secara signifikan memotong kebutuhan logistic khususnya rumah tangga. Selain membantu dalam hal perekonomian, penanaman sayur secara mandiri juga meningkatkan kesehatan karena dilakukan secara organik atau tanpa pestisida (Pharmawati et al., 2019; Purwono et al., 2021).

Berkebun sayur di halaman rumah dapat juga dilakukan oleh masyarakat perkotaan. Dengan ketersediaan lahan yang sempit, metode vertikultur merupakan cara yang tepat dalam kegiatan berkebun (Hermanto et al., 2020; Surtinah, 2019; Wasonowati, 2021). Vertikultur merupakan sistem budidaya pertanian yang dilakukan secara vertikal (bertingkat). Tujuan dari vertikultur adalah menyiasati lahan sempit di wilayah perkotaan. Sehingga orang yang tidak memiliki lahan atau tanah tetap bisa produktif di bidang pertanian (Ariati, 2017; Solikah et al., 
2020). Tidak hanya pada rumah tangga, penerapan berkebun sayur juga dapat dilakukan di asrama yang melibatkan anak didik didalamnya. Salah satunya adalah Asrama Putra Sang Timur yang berada ditengah kota Yogyakarta. Secara umum, asrama ini lebih banyak dihuni oleh siswa (laki-laki) yang pada dasarnya belum mengetahui jenis sayuran dan cara penanamannya. Maka pelatihan budidaya secara vertikultur ini menggunakan sayur yang paling sering dikonsumsi seperti pakcoy dan caisim.

Sayuran pakcoy dan caisim adalah tanaman yang dianggap lebih mudah untuk dijadikan tanaman kebun dengan konsep vertikultur. Menurut (Izhar et al., 2016; Mardilla \& Pratiwi, 2021), pertumbuhan pakcoy lebih baik pada vertikultur dibandingkan di lahan kebun pertanian pada umumya. Tanaman caisim lebih banyak dipilih sebagai tanaman di teknik penanaman vertikultur (Hadi et al., 2017). Produksi sawi caisim juga lebih banyak pada teknik vertikultur dibandingkan dengan penanaman konvensional (Thana, 2016).

\section{METODE}

Kegiatan pengabdian masyarakat dilakukan secara langsung atau tatap muka dengan metode ceramah dan demonstrasi dan dilanjutkan dengan pelatihan/praktik menggunakan media vertikultur (Gambar 1). Pelaksanaan pengabdian kepada masyarakat dilakukan pada masa pandemi, sehingga pelaksanaannya mengikuti protokol kesehatan yaitu cuci tangan, menjaga jarak, dan memakai masker selama beraktivitas.

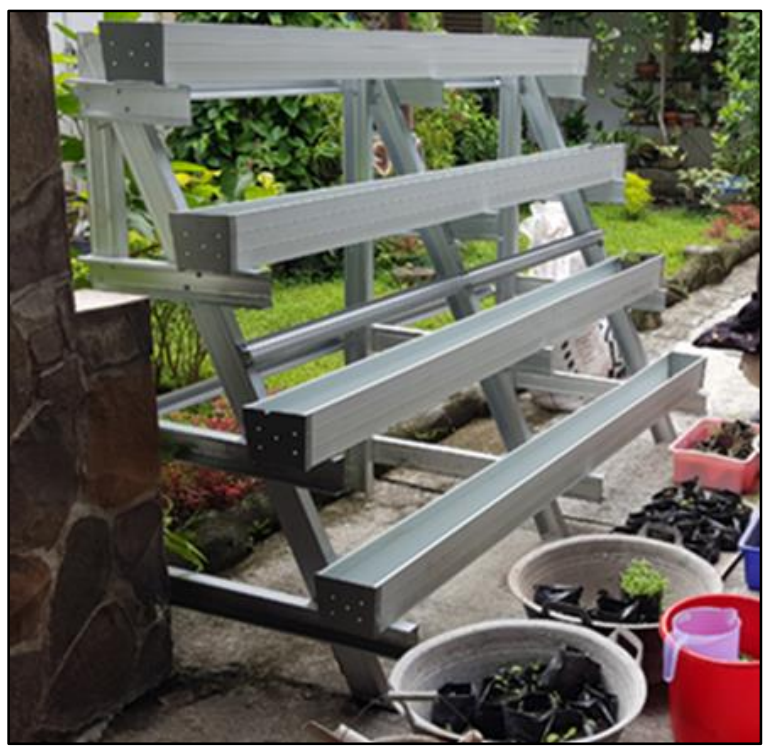

Gambar 1. Media Vertikultur yang Disediakan

\section{HASIL PEMBAHASAN}

Kegiatan diawali dengan pemberian materi lembar mengenai budidaya vertikal teknik pokcoy dan caisim yang telah diberikan oleh pemateri (Gambar 2). Setelah itu memberikan penjelasan tentang tahapan pekerjaan penanaman. Acara selanjutnya dilakukan praktik langsung menanam sayuran. Untuk kegiatan ini panitia sudah menyiapkan bibit caisim dan pakcoy yang sudah disemai di polybag kecil selama 1 minggu, sehingga pelaksanaan pengabdian ini langsung menanam bibit yang sudah tersedia.
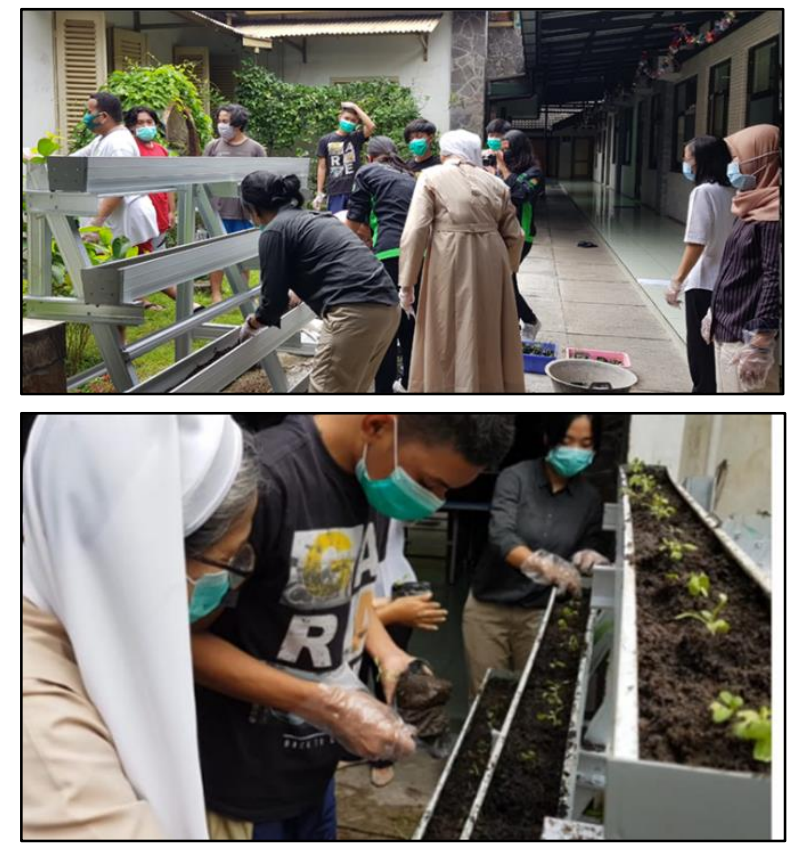

Gambar 2. Pemberian Kompos pada Media Vertikultur

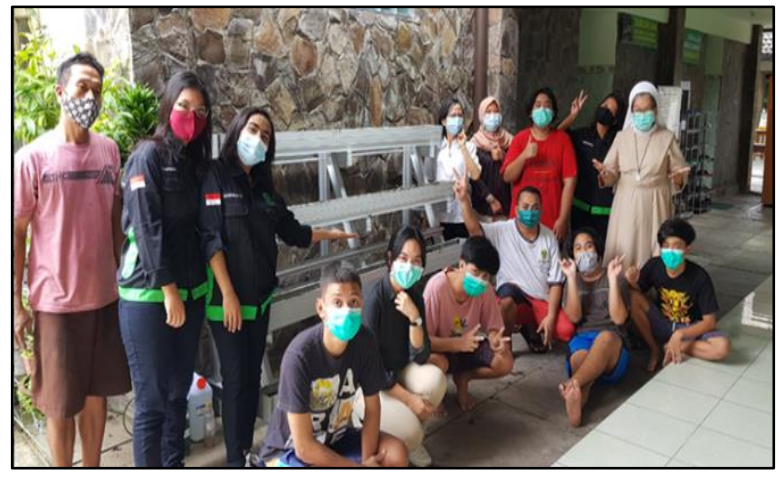

Gambar 3. Tim Pengabdian kepada Masyarakat

Pengisian tanah pengomposan, penanaman dan penyiraman benih dilakukan langsung oleh siswa dan tenaga pendidik di Asrama Sang Timur Putra dengan dipandu oleh pemateri layanan (Gambar 2). Setelah selesai praktek, kegiatan selanjutnya yaitu memberikan beberapa paket 
bibit sayuran pakcoy dan caisim agar mahasiswa dan warga asrama bisa menanam sayuran tersebut secara berkesinambungan.

\section{KESIMPULAN}

Pada kegiatan pengabdian masyarakat yang dilakukan di Asrama Putra Sang Timur, para siswa dan tim lainnya sangat antusias dalam praktik penanaman. Hasil dari kegiatan ini, para siswa lebih memahami teknik penanaman. Dimulai dari penyemaian benih dalam polybag, teknik penyiraman benih, umur bibit yang baik untuk dilakukan pemindahan ke sistem vertikultur, jenis tanah kompos dan pemeliharaan tanaman sayuran selama masa tanam. Dengan dilakukannya pelatihan budidaya sayur secara vertikultur ini, diharapkan dapat membantu siswa dan pengelola Asrama Putra Sang Timur dalam meningkatkan kemandirian pangan.

\section{DAFTAR PUSTAKA}

Ariati, P. E. P. (2017). Produksi Beberapa Tanaman Sayuran dengan Sistem Vertikultur di Lahan Pekarangan. Jurnal Agrimeta, 7(13), 76-86.

Hadi, S. N., Rahayu, A. Y., \& Widiyawati, I. (2017). Penerapan Teknologi Berkebun Sayur secara Vertikultur pada Siswa Sekolah Dasar di Purwokerto, Jawa Tengah. Panrita AbdiJurnal Pengabdian Pada Masyarakat , 1(2), 114-119.

Hermanto, D., Ismillayli, N., Zakirrahman, M., Jannaturrayyan, S., \& Nartiadi, L. A. (2020). Integrasi Perkebunan, Perikanan, dan Peternakan untuk Mewujudkan Rumah Pangan Lestari di Desa Banyu Urip, Lombok Tengah. Jurnal Pengabdian Pada Masyarakat, 5(2), 409-414. Izhar, A., Heddy, S., \& Sitawati, undefined. (2016). Pengaruh Media Tanam dan Bahan Vertikultur terhadap Pertumbuhan dan Hasil Tanaman Pakcoy ( Brassica juncea L.). Jurnal Produksi Tanaman, 4(7), 562-569.

Mardilla, M., \& Pratiwi, A. (2021). Budidaya Tanaman Pakcoy (Brassica Rapa Subsp. Chinensis) Dengan Teknik Vertikultur Pada Lahan Sempit Di Kelurahan Penaraga Kecamatan Raba Kota Bima. Jurnal Pengabdian Magister Pendidikan IPA, 4(1). https://doi.org/10.29303/JPMPI.V4I1.537

MPR UNAS. (2021). PKM Dosen Pertanian UNAS Dorong Masyarakat Kota Untuk Mulai

\section{Urban \\ Farming}

https://www.unas.ac.id/berita/pkm-dosenpertanian-unas-dorong-masyarakat-kotauntuk-mulai-urban-farming/

Nurholis, N. (2021). Kawasan Rumah Pangan Lestari sebagai Upaya Peningkatan Ketahanan Pangan Masyarakat Pada Masa Pendemi Covid-19. Jurnal Ilmiah Pangabdhi, 7(1), 710.

Pharmawati, M., Ciawi, Y., Wrasiati, L. P., \& Wijaya, I. M. A. S. (2019). Pelatihan Budidaya Sayuran Secara Hidro-Vertikultur di Desa Datah Karangasem Sebagai Kegiatan Mitigasi Bencana. Buletin Udayana Mengabdi, 18(2).

Purwono, P., Ristiawan, A., Ulya, A. U., Juniatmoko, R., \& Astuti, S. P. (2021). Peningkatan Keterlibatan Masyarakat dan Nilai Ekonomi Limbah Rumah Tangga dan Pasar melalui Budidaya Maggot Black Soldier Fly. Jurnal Pengabdian Pada Masyarakat, 6(2), 610-618. https://doi.org/10.30653/002.202162.546

Rosyad, A., Astuti, T. Y., \& Tini, E. W. (2020). Penerapan Urban Farming untuk Meningkatkan Kelestarian Lingkungan pada Hunian Perumahan. Jurnal Dinamika Pengabdian (JDP), 6(1), 32-46. https://doi.org/10.20956/JDP.V6I1.8531

Solikah, U. N., Rahayu, T., \& Dewi, T. R. (2020). Optimalisasi Urban Farming dengan Vertikultur Sayuran. WASANA NYATA, 3(2), 168-173. https://doi.org/10.36587/WASANANYATA. V3I2.529

Surtinah, S. (2019). Potensi Pekarangan Sempit untuk Memenuhi Kebutuhan Pangan Keluarga di Pekanbaru. Jurnal Agribisnis, 20(2), 196205.

https://doi.org/10.31849/AGR.V20I2.1680

Thana, D. P. (2016). Budidaya Vertikultur Tanaman Sawi Hijau ( Brassica Juncea L ) Menggunakan Pupuk Organik Cair Elang Biru. AgroSainT, 7(2), 58-62. https://doi.org/10.47178/AGRO.V7I2.531

Wasonowati, C. (2021). Pengembangan Sayuran Lokal dengan Vertikultur pada Pekarangan Keluarga (Family Farming). Jurnal Ilmiah Pangabdhi, 7(1), 11-14. https://doi.org/10.21107/PANGABDHI.V7I1. 8809 